CARPATHIAN JOURNAL OF FOOD SCIENCE AND TECHNOLOGY

journal homepage: http://chimie-biologie.ubm.ro/carpathian_journal/index.html

\title{
ANISAKIASIS OF FISH PRODUCTS AND ITS SANITARY CHARACTERISTICS
}

\author{
Tatyana V. Shevchuk ${ }^{1 凶}$ \\ Vinnitsa National Agrarian University, 3, Sunny str., Vinnitsa, 21008, Ukraine \\ ${ }^{\bowtie}$ Tatjana.Melnikova@ukr.net
}

https://doi.org/10.34302/crpjfst/2020.12.3.14

Article history:

Received:

13 March 2020

Accepted:

18 June 2020

Keywords:

Anisakis simplex;

Anisacidosis;

Invasion;

Sanitary condition;

Fish products.

\section{ABSTRACT}

The article is devoted to the study of the defeat of fish products (Atlantic herring (Clupea harenqus) with fresh-frozen, salted, pickled and smoked) parasitic nematodes Anisakis simplex. It was noted that for the period from 2015 to 2018, the rate of invasion by this parasite increased from 9.2 to $54.4 \%$. It was experimentally established that fish of various culinary processing had different degrees of helminth damage. The most anisizoid larvae were in pickled herring, and least of all - in smoked. It is obvious that the established differences in digital data are associated not only with the type of culinary processing, but with the observance of sanitary standards for the storage of fish raw materials and finished products. Removing the viscera from the fish carcass and observing the thermal regime significantly reduce the level of invasion.

\section{Introduction}

Fish and fish products are valuable food products - a source of high-quality proteins, unsaturated fatty acids, fat-soluble vitamins and minerals. Fishing is one of the main sources of providing residents of Ukraine with full-fledged food. In the structure of the Ukrainian fish market, about $80 \%$ is imported products. An increase in the supply of fish from abroad to the domestic market of Ukraine has increased the frequency of detection of helminthological pathogens previously diagnosed sporadically, in particular, opisthorchiasis, clonorhosis, metagoniosis, nanofeetosis, diophilobothiosis, coriandrosis, anisakidosis, and others.

According to the literature, virtually all sea fish can be infected with different types of worms, up to 30 species of which constitute a potential danger to humans or cause unwanted changes in fish, as in technological raw materials. Of the helminthiasis dangerous to humans in sea fish most often occur nematodes of the family of Anisakids (Mikulich, 2013; Shibata, Ueda, Akaike \& Saida, 2014).

Anisakiasis is a zoonotic gelmina characterized by a defeat of the gastrointestinal tract as a result of parasitism in the human body at the stages of the larvae of the worm family Anisakidae.Anisakis - pathogenic worms, the representatives of nematodes of the family Anisakidae (Anisakis simplex, Pseudoterranova decipiens, Hysterothylacium aduncum, Contracaecum osculatum). According to studies by various scientists, fish invasiveness with anisakiasis reaches high rates (20-50\%). Localized in the body, on the surface or in the tissues of the internal organs, rarely in the muscles (often below the middle line of the body of fish), sea and passage Pacific fish (cod, mackerel, hake, flounder, knot, herring, pink salmon etc.) (Gaevskaya, 2005; Baird et al., 2014).

It is dangerous that the parasites are stored in the fish after freezing, harvesting and heat treatment. Larvae of A. simplex can survive and 
retain allergenic properties even during longterm storage in frozen form $\left(-20 \pm 2{ }^{\circ} \mathrm{C}\right.$ for 11 months). Is can tolerate a temperature rise of up to $45^{\circ}-60^{\circ} \mathrm{C}$ and above they die within 10 minutes. Thus, the thermal processing of fish does not guarantee its decontamination from the anisotropic larva (Sondak, Gritsik \& Rud, 2006; Buchmann \& Mehrdana, 2016).

However, the relationship between the degree of invasion of Anisakis and the various types of culinary processing of fish has not yet been studied. Obviously, a detailed study of this issue can improve sanitary safety and reduce the number of low-quality products.

According to monitoring of the Ukrainian trading network, currently frozen fish products dominate the market, accounting for about $90 \%$ of all imports. In addition, there are different types of fish processing: marinades, cheeses, pickled, smoked and others. The most popular and affordable object is Atlantic herring (about $20 \%$ of all imports). It was repeatedly noted earlier that this species is characterized by the highest prevalence of Anisakidae invasion (up to $100 \%$ ), respectively, such products can be potentially dangerous for the consumer (Gaevskaya, 2005; Baird et al., 2014). In this regard, the aim of our study was to study the interannual dynamics of the number of Anisakidae parasites in the Atlantic herring (Clupea harenqus) after various culinary processing.

\section{Materials and methods}

The main goal of the study is to determine the extent of herring damage during various culinary treatments by the larvae of Anisakis simplex in the markets of Vinnitsa (by 20152018 years). The object of the study was herring frosting, salting, smoked, and marinated herring, the subject - the dynamics of lesion with anisakis.

The selection fish products samples was carried out 2015 - 2018 year by the work of the expansion network in accordance with the established rules and regulations. In the course of research are used same methods such as organoptic and parasitological. The parasitological examination of fish reveals visible parasites, as well as parasites, muscles, under the skin or shines. At the same time, we paid attention to the inclusions, which differ in color or consistency from normal tissues and form regions of meat of sparse consistency. To detect parasites in meat use a method of parallel cuts (Bogatko, Vlasenko \& Golub, 2011; Fotina, Berezovskiy, Petrov \& Gorchanok, 2013).

Detection of parasites or inclusion, like living parasites, is initially considered under magnifying glass or binocular. Then, they are considered under the small and middle levels of the microscope. The vital activity of parasites is determined by the method of irritation.

The following parameters were determined to the dynamics of anisakis in different types of culinary processing: the number of damaged specimens, the severity of the invasion, the intensity of the invasion and the index of invasion. The number of specimens affected was determined by simple counting when the fish were opened and examined. Extensiveness of the invasion was determined by dividing the number of damaged specimens by the number of specimens (25 pieces) and multiplying by 100 . The intensity of the invasion was determined by counting the parasites of one fish. The invasion index was determined by dividing the number of parasite larvae into the total number of parasites found in the sample (Bogatko et al., 2011). A sanitary-microbiological assessment of the affected fish was carried out using a reaction to reductase and peroxidase (benzyidine test) (Fotina et al., 2013).

The digital material was processed statistically. The resulting digital data was processed using the MS EXEL 98 and Windows program, statistically processed by Student. The results were considered statistically significant at $\mathrm{p}<0.1(*), \mathrm{p}<0.01(* *), \mathrm{p}<0.001(* * *)$.

\section{Results and discusions \\ 3.1.Results}

It has been experimentally established that different types of fish products have different levels of infection with Anisakis simplex larvae. Smoked fish suffered the least. However, in the 
period from 2015 to 2018, the rate of invasion increased by this parasite increased from 9.2 to $54.4 \%$. Samples of salty fish at the beginning of our study had no parasites (2015). Since 2016, it has grown by $60.4 \%$. The largest infection of anisakis salty fish has in 2017 (Fig. 1).

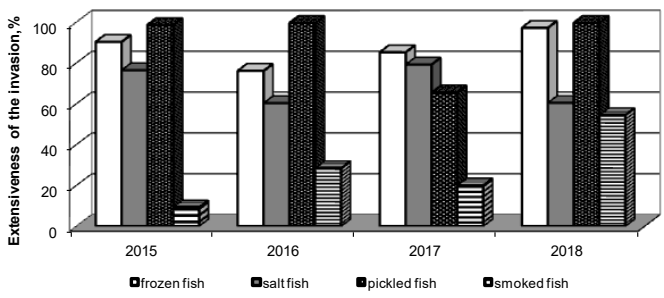

Figure 1. Dynamics of invasion of herring Anisakis simplex of different culinary processing

The graphic material shows that marinated fish products are the most affected. The degree of damage has reached almost 100\%. This means that virtually every carcass of fish during the analysis was infected with parasites. Only in
2017, the level of invasion decreased by $33 \%$ compared with the previous one. Frozen fish also had a high incidence of defeat by Anisakis simplex larvae. In the baseline (2015) and reporting (2018) years, the severity of the invasion was close to $100 \%$. The least was contaminated with frozen fish products in 2016 (by $21.2 \%$ compared to the reported year).

Parasitological studies have shown that in the base year (2015) all marinated fish were damaged by Anisakis simplex larvae. In it we counted up to 57 larvae per 1 carcass of fish. In addition, the marinated herring had the highest rate of invasion (33.3 units / carcass) compared to other types of fish products (Table 1). In the reported year (2018) The number of carcasses of fish with larvae of the parasitic nematode in the group of frozen and pickled products was the same. However, in the marinated fish, the invasion index was 10 units higher compared to frozen fish. In this group, we found the highest intensity of invasion (Table 1).

Table 1.The dynamics of infection to $A$. simplex of fish products over the past 5 years $(M \pm m, n=25)$

\begin{tabular}{|l|c|c|c|c|}
\hline \multirow{2}{*}{ Indicator } & \multicolumn{3}{|c|}{ Type of fish products (Atlantic herring (Clupea harenqus) } \\
\cline { 2 - 5 } & frozen & salt & pickled & smoked \\
\hline \multicolumn{5}{|c|}{2015 year (base) } \\
\hline $\begin{array}{l}\text { The number of } \\
\text { specimens affected, } \\
\text { units }\end{array}$ & $23,6 \pm 0,52$ & $19,3 \pm 0,06^{* * *}$ & $25,0 \pm 0,01^{*}$ & $2,3 \pm 0,91^{* * *}$ \\
\hline $\begin{array}{l}\text { The intensity of the } \\
\text { invasion, units }\end{array}$ & $5-19$ & $7-20$ & $9-57$ & $1-17$ \\
\hline $\begin{array}{l}\text { The invasion index, } \\
\text { units }\end{array}$ & $12,6 \pm 1,78$ & $13,5 \pm 0,77$ & $33,3 \pm 0,85^{* * *}$ & $9,03 \pm 0,45^{*}$ \\
\hline $\begin{array}{l}\text { The number of } \\
\text { specimens affected, } \\
\text { units }\end{array}$ & $19,0 \pm 1,03$ & $15,0 \pm 0,07 * * *$ & $24,9 \pm 0,03 * *$ & $7,1 \pm 0,09^{* * *}$ \\
\hline $\begin{array}{l}\text { The intensity of the } \\
\text { invasion, units }\end{array}$ & $3-15$ & $1-23$ & $7-43$ & $3,5 \pm 0,09 * * *$ \\
\hline $\begin{array}{l}\text { The invasion index, } \\
\text { units }\end{array}$ & $9,3 \pm 0,03^{*}$ & $12,3 \pm 0,36$ & $23,5 \pm 3,31^{* *}$ & $3-7$ \\
\hline
\end{tabular}




\begin{tabular}{|l|c|c|c|c|}
\hline \multicolumn{5}{|c|}{2017 year } \\
\hline $\begin{array}{l}\text { The number of } \\
\text { specimens affected, } \\
\text { units }\end{array}$ & $21,3 \pm 0,71^{* *}$ & $19,8 \pm 1,69$ & $23,9 \pm 2,03$ & $5,3 \pm 2,73$ \\
\hline $\begin{array}{l}\text { The intensity of the } \\
\text { invasion, units }\end{array}$ & $3-25$ & $5-19$ & $7-28$ & $0-3$ \\
\hline $\begin{array}{l}\text { The invasion index, } \\
\text { units }\end{array}$ & $14,3 \pm 0,06$ & $12,0 \pm 0,31^{*}$ & $17,5 \pm 4,35^{* *}$ & $1,5 \pm 0,01^{* * *}$ \\
\hline \multicolumn{2}{|c|}{2018 year (reporting) } \\
\hline $\begin{array}{l}\text { The number of } \\
\text { specimens affected, } \\
\text { units }\end{array}$ & $24,3 \pm 2,75$ & $15,1 \pm 3,71$ & $24,9 \pm 1,33$ & $13,6 \pm 2,75^{*}$ \\
\hline $\begin{array}{l}\text { The intensity of the } \\
\text { invasion, units }\end{array}$ & $5-23$ & $1-18$ & $11-37$ & $3-15$ \\
\hline $\begin{array}{l}\text { The invasion index, } \\
\text { units }\end{array}$ & $14,3 \pm 2,75$ & $9,5 \pm 0,33^{* * *}$ & $24,8 \pm 7,24$ & $9,3 \pm 0,33$ \\
\hline
\end{tabular}

In the dynamics of the intensity of the invasion over the past five years, this indicator was the highest in the group of frozen fish and salty fish products in 2017, in the group of pickled and smoked fish - in 2018. A group of frozen fish, this figure has increased by 1.7 units. In salted herring, for the last five years, the parasite larvae were less than 4.0 units per 1 carcass of fish $(p<0.001)$. In the group of pickled fish products, the invasion index decreased by 8.5 units ( $\mathrm{p}<0.001)$, while smoked fish - on the contrary, increased by 0.27 units $(\mathrm{p}<0.01)$.

During our previous studies, the infection of the marinated herring Anisakis simplex in the markets of Vinnitsa and villages of urban type Lityn was studied. In 2019, we repeated the experiment to study the viability of the larvae of this parasite. The results of the comparative analysis are presented in table 2 .

Table 2. The dynamics of $A$. simplex infected marinated herring and the presence of live larvae $(M \pm m, n=5)$

\begin{tabular}{|l|c|c|}
\hline \multicolumn{1}{|c|}{ Index } & \multicolumn{2}{c|}{ Year: } \\
\cline { 2 - 3 } & 2015 & 2018 \\
\hline The intensity of infection with parasites, units & $7,6 \pm 1,88$ & $7,2 \pm 5,22$ \\
\hline $\begin{array}{l}\text { Intensity of infection with parasites of the abdominal } \\
\text { cavity, units/kg }\end{array}$ & 43,0 & 35,6 \\
\hline including live parasites, units & $0,20 \pm 0,19$ & $1,7 \pm 1,40$ \\
\hline$\%$ of total & 2,63 & 23,19 \\
\hline
\end{tabular}

The material in the table indicates an increase in the number of live larvae of the $A$. simplex in fish in the reporting year 2019. At the same time, the index of invasion in 2015 and 2018 was almost the same. By the number of parasites per kilogram of edible part of the fish, 
the invasion index decreased by 7.4 units, but remains fairly large.

The connection between the defeat of fishery products by $A$. simplex larvae and the sanitary condition was investigated. During the study of the reaction to peroxidase, a positive effect was found in gills of all types of culinary processing. In muscle extracts, the reaction to reductase was positive only in the group of pickled products (table 3 ).

Table 3.Peroxidase and Reductase tests for fish products $(M \pm m, n=5)$

\begin{tabular}{|c|c|c|c|c|}
\hline \multirow{2}{*}{ Indicator } & \multicolumn{4}{|c|}{ Kind of fish processing } \\
\hline & frozen & salt & pickled & smoked \\
\hline $\begin{array}{l}\text { Peroxidase test: } \\
\text { - gills }\end{array}$ & positive $(+)$ & + & + & + \\
\hline - muscles & negative (-) & - & + & - \\
\hline $\begin{array}{l}\text { Reductase test, time of } \\
\text { counting change of color, } \\
\text { minutes: } \\
\text { - up to } 40 \text { minutes }\end{array}$ & $\begin{array}{l}\text { negative, the } \\
\text { indicator did not } \\
\text { change the color } \\
(-)\end{array}$ & - & - & - \\
\hline $\begin{array}{l}\text { - from } 40 \text { min up to } 2.5 \\
\text { hours }\end{array}$ & - & - & $\begin{array}{l}\text { indicator } \\
\text { changed the } \\
\text { color }(+)\end{array}$ & - \\
\hline - more than 2.5 hours & - & - & + & + \\
\hline
\end{tabular}

The reaction to the reductase was positive in pickled and smoked fish. In addition, in the marinated herring, the indicator changed the color for almost 1 hour. All other samples of fish products had a negative reaction to reductase.

\subsection{Discussions}

Anisakiasis was first detected in the Netherlands in 1955 after eating slightly salted herring. Every year in many countries new cases are registered. According to studies of various scientists, the invasiveness of fish with anisakiasis reaches high rates. The greatest incidence is observed in Atlantic herring - (59$100 \%$ ), the frequency of invasion is $1-38$ individuals, the invasion index is 12 larvae per carcass of fish (Gaevskaya, 2005; Baird et al., 2014). Our studies have confirmed this trend of Atlantic herring pollution. The total volume of herring samples of different types of culinary processing in Vinnitsa was somewhat higher than the data on the loss of imported fish, as shown in the article. F. Baird et al. aaccording to their data, the degree of damage by parasites of fish was within $59 \%$, the intensity of the invasion - up to 38, and the index of invasion up to 12 (Baird et al., 2014). However, according to experimental data R.V. Puzyr, S.A. Tkachuk, (2013) the extensiveness of the

invasion - the herring was $89 \%$, the intensity of the invasion - 7-22 units. Apparently, discrepancies in the data are related not only to the type of culinary processing, but also to the observance of sanitary norms for the storage of fish raw materials and finished products.

In studying the localization of larvae of anisakis, it was established that the determining factor is not a kind of culinary processing, but a kind of processing of raw materials. Most of the invasions were found on the internal organs of fish. According to literature data, the abdominal cavity and internal organs (82.2\%), less often the muscles of the abdominal wall (13.3\%) and back muscles $(4.5 \%)$ are most often affected (Grigoryeva, 2009). There are cases of invasion not only in frozen fish, but even in fish canned fish from whole fish (Pravettoni, Primavesi \& Piantanida, 2012; Caballero et al., 2013; Baird et al., 2014). Therefore, in our opinion, removal of 
insects from the carcass of fish can reduce the level of invasion.

According to the results of our research, the largest number of larvae was found in the intestines of pickled fish, and the least - in cartridges of smoked fish. We found that in the period from 2015, the degree of invasion of smoked fish has almost doubled, and salty - by $60.4 \%$. Perhaps in the production of such fish products, producers did not sufficiently control the quality of raw materials or used inappropriate fish.

An analysis of experimental data showed that for one pickled herring, according to calculations, more than 5 larvae. In accordance with sanitary norms (Bogatko et al., 2011; Fotina et al., 2013) such products are not allowed for sale In our opinion, this is due to the selection of low-quality raw materials that have not been properly treated with cold. Seafood disinfection from anisakis larvae can be carried out by freezing and heating (Mikulich, 2013; Buchmann \& Mehrdana, 2016, Rodríguez et al., 2016). Typically, pickled fish is made from previously frozen foods. In Europe and the USA, sanitary rules regulate the freezing of fish, which cannot be subjected to further heat treatment at $20^{\circ} \mathrm{C}$ for 5 days. In ordinary physiological and acetic acid solutions used to prepare fish, Anisakias larvae can remain viable for many days or even months (Mikulich, 2013; Buchmann \& Mehrdana, 2016, Rodríguez et al., 2016). Also, the cause may be improperly prepared marinade with a low salt content (less than 14\%), favorable for the life of larvae.

The smallest contamination was observed in smoked fish products. The removal of the intestines from the fish before smoking caused a decrease in the degree of invasion of the body by $78 \%$. Anisakias larvae can tolerate fever up to $45^{\circ} \mathrm{C}$, but at a temperature of $60^{\circ} \mathrm{C}$ and above they die within 10 minutes. However, thermal treatment of fish in the temperature range 45-60 - $\mathrm{C}$ does not guarantee its disinfection from larvae (Baird et al., 2014; Prester, 2015), as evidenced by their presence in smoked samples.

We also established a connection between the sanitary state of fish products and damage to
A. simplex larvae. It is proved that the more parasites were detected in fish (pickled herrings), the better the reaction was to peroxidase and reductase. This, in turn, indicates the damage to fish products by microorganisms and their inability to consume people. For example, according to the reaction to the reductase, marinated fish products were classified as conditionally fresh. Similar data were obtained in other studies by other researchers (Puzyr \& Tkachuk, 2013; Shibata et al., 2014).

\section{Conclusions}

The practical significance of this study is to increase the effectiveness of sanitary and epidemiological control of fish products and public awareness of the risk of anisakiosis. Studies have shown that in recent years there has been a tendency to increase the invasion of herring on anisaki of all types of cooking. The highest intensity, intensity and index of invasion were found in pickled fish. The analysis of carcasses showed that up to $89 \%$ of all larvae are localized in the abdominal cavity. Smoked fish had the slightest damage with anisakis.

Anisakis simplex larva invasion negatively affects the sanitary state of fishery products. It was found that herring, marinated with a large number of parasites, had a positive reaction to peroxidase and reductase. In the future, we will investigate the biochemical composition and properties of fish products depending on the degree of defeat by Anisakis simplex larvae. We will also develop biologically active additives that quickly disinfect live larvae of this species.

\section{References}

Baird, F., Gasser, R., Jabbar, A. et al. (2014). Foodborne anisakiasis and allergy. Molecular and Cellular Probes, 28, 167-74. Retrieved from doi: 10.1016/j.mcp.2014.02.003.

Bogatko, N. M., Vlasenko, V. V. \& Golub, O.Yu. (2011). ZdIysnennya derzhavnogo veterinarno-sanItarnogo naglyadu ta kontrolyu na potuzhnostyah z pererobki ribi 
ta riboproduktIv $\mathrm{u}$ vIdpovIdnostI do mIzhnarodnih vimog: Metod. rekomend. BIla Tserva. [Bogatko, N. M., Vlasenko, V. V. \& Golub, O.Yu. (2011). Implementation of state veterinary and sanitary supervision and control at facilities for processing fish and fish products in accordance with international requirements: Metod. rekomend. BIla Tserva.]

Buchmann, K. \& Mehrdana, F. (2016). Effects of anisakid nematodes Anisakis simplex (s.1.), Pseudoterranova decipiens (s.1.) and Contracaecum osculatum (s.1.) on fish and consumer health. Food and Waterborne, 4, 13-22. Retrieved from doi.org/10.1016/j.fawpar.2016.07.003.

Caballero, M., Asero, R., Antonicelli, L. et al. (2013). Anisakis allergy componentresolved diagnosis: clinical and immunologic differences between patients from Italy and Spain. International Archives of Allergy and Immunology, 162, 39-44. Retrieved from doi: 10.1159/000351056.

Carballeda-Sangiao, N., Olivares, F., Rodriguez-Mahillo, A. I. et al. (2014). Identification of autoclave-resistant Anisakis simplex allergens. Journal of Food Protection, 77, 605-09. Retrieved from doi: 10.1645/GE-1751.1.

Fotina, T.I., Berezovskiy, A.V., Petrov, R.V. \& Gorchanok, N.V. (2013). Veterinarnosanitarnaya ekspertiza ryibyi, morskih mlekopitayuschih i bespozvonochnyih zhivotnyih. Vinnitsa, Ukraine: Novaya Kniga. [Fotina, T.I., Berezovskiy, A.V., Petrov, R.V. \& Gorchanok, N.V. (2013). Veterinary and sanitary examination of fish, marine mammals and invertebrates. Vinnitsa, Ukraine: Novaya Kniga.]

Gaevskaya, A. V. (2005). Anizakidnyie nematodyi i zabolevaniya, vyizyivaemyie imi u zhivotnyih i cheloveka. Sevastopol: EKOSI-Gidrofizika. [Gaevskaya, A. V. (2005). Anizakid nematodes and diseases caused by them in animals and humans. Sevastopol: EKOSI-Gidrofizika.]

Grigoryeva, V.V. (2009). Evaluation of the effectiveness of fish disinfection in anisacidosis. Agrarian Bulletin of the Urals, 3(57), 83.

Ivanovic, J. et al. (2015). Anisakis Infection and Allergy in Humans. Procedia Food Science, 5, 101-104.

doi: 10.1016/j.profoo.2015.09.028.

Kolkhir, P., Balakirski, G., Merk, H. et al. (2016). Chronic spontaneous urticaria and internal parasites - a systematic review. Allergy, 71, 308-22. Retrieved from doi: 10.1111/all.12818.

Lin, A., Nepstad, I., Florvaag, E. et al. (2014). An extended study of seroprevalence of anti-Anisakis simplex IgE antibodies in Norwegian blood donors. Scandinavian Journal of Immunology, 79, 61-67. Retrieved from doi: full/10.1111/sji.12130.

Mikulich, E. L. (2013). Vidovoe raznoobrazie parazitofaunyi nekotoryih vidov morskih ryib, realizuemyih $\mathrm{v}$ torgovoy seti: Monografiya. Gorki. [Mikulich, E. L. (2013). Species diversity of the parasite fauna of some species of marine fish sold in the trading network: Monografiya. Gorki.]

Nieuwenhuizen, N. \& Lopata, A. (2014). Allergic reactions to Anisakis found in fish. Current Allergy and Asthma Reports, 14, 455. Retrieved from doi: $10.1007 / \mathrm{s} 11882$ 014-0455-3.

Pravettoni, V., Primavesi, L. \& Piantanida, M. (2012). Anisakis simplex: current knowledge. European Annals of Allergy and Clinical Immunology, 44, 150-156. Retrieved from doi: 10.1016/j.euprot.2014.06.006.

Prester, L. (2015). Seafood Allergy, Toxicity, and Intolerance: A Review. Journal of the American College of Nutrition, 7, 1-13. Retrieved from doi: 10.1080/07315724.2015.1014120. 
Puzyr, R.V. \& Tkachuk, S.A. (2013). Laboratorni doslidzhennia m'iasa ryby urazhenoi lychynkamy anizakid. $Z b$. nauk. Prats NUBiP. Retrieved from: http://nbuv.gov.ua/j-pdf/Nd_2013_5_12.pdf Accessed May 12, 2013. [Puzyr, R.V. \& Tkachuk, S.A. (2013). Laboratory studies of fish meat infected with anisakis. Zb. nauk. Prats NUBiP. Retrieved from: http://nbuv.gov.ua/j-pdf/Nd_2013_5_12.pdf Accessed May 12, 2013.]

Rodríguez, C., Borja, J., Bartolomé, B. et al. (2016). Hidden allergens: a challenge for allergists. Annals of Allergy, Asthma \& Immunology, 116, 85-86. Retrieved from doi:10.1016/j.anai.2015.10.019.

Shibata, E., Ueda, T., Akaike, G. \& Saida, Y. (2014). CT-findings of gastric and intestinal anisakiasis. Abdominal Radiology, 39, 25761. Retrieved from doi: $10.1007 / \mathrm{s} 00261-$ 014-0075-3

Sondak, V.V., Gritsik, O.B. \& Rud, G. (2006). Invaziyni hvorobi rib: Navch. PosIbnik. RIvne: NUVGP. [Sondak, V.V., Gritsik, O.B. \& Rud, G. (2006). Invasive fish diseases: Navch. PosIbnik. RIvne: NUVGP.] 